\title{
Penerapan Sistem Autentikasi Sertifikat Sebagai Pengambil Keputusan Validasi Sertifikat Pada Perguruan Tinggi
}

\author{
Untung Rahardja ${ }^{1}$ \\ Eka Purnama Harahap ${ }^{2}$ \\ Gilang Fresandy ${ }^{3}$
}

Alumni Universitas Indonesia Program Studi Magister Teknologi Informasi ${ }^{1}$, Dosen STMIK Raharja Jurusan Sistem Informasi ${ }^{2}$, Mahasiswa STMIK Raharja Jurusan Sistem Informasi ${ }^{3}$ Email: untung@raharja.info ${ }^{1}$,ekapurnamaharahap@raharja.info ${ }^{2}$,fresandy@raharja.info ${ }^{3}$

\begin{abstract}
ABSTRAK
Pengembangan sistem adalah suatu cara untuk memberikan inovasi terbaru pada Perguruan Tinggi dimana sistem yang dibuat harus berdasarkan apa yang dibutuhkan para Pribadi Raharja. Autentikasi sertifikat dimaksudkan untuk melengkapi dan mengoptimalkan Validasi Sertifikat pada PO Sidang, salah satunya terdapat poin Validasi Sertifikat dan Tridharma. Mahasiswa harus melakukan validasi dengan cara submit via website dan akan di review oleh admin. Dengan hadirnya autentikasi sertifikat ini admin bisa mengecek keaslian dari sertifikatnya dimanapun dan kapanpun. Dan sertifikat akan terdokumentasi dengan baik di dalam database. Jadi admin bias lebih baik lagi dalam melakukan validasi dan mengurangi potensi pemalsuan sertifikat.
\end{abstract}

\begin{abstract}
System development is a way to provide the latest innovations in Higher Education where the system created must be based on what is needed by Personal Raharja. Certificate authentication for Structure and optimal Validation of Certificates on PO Session, one of the points. Certificate Validation and Tridharma. Students must validate by submitting via website and will be reviewed by admin. With the presence of this certificate authentication admin can check the authenticity of the certificate wherever and whenever. And certificates will be well documented in the database. So admin bias is better in validating and reducing the potential for certificate forgery.
\end{abstract}

\section{PENDAHULUAN}

Peniruan atau pemalsuan adalah perbuatan dasar dari pencurian, yaitu sebuah upaya yang dilakukan untuk mendapatkan sesuatu yang nantinya akan di klaim oleh peniru. Tindak pidana berupa pemalsuan suatu surat dapat kita jumpai ketentuannya dalam Pasal 263 Kitab Undang Undang Hukum Pidana (“KUHP”) yang berbunyi: (1) Barang siapa membuat surat palsu atau memalsukan surat yang dapat menimbulkan sesuatu hak, perikatan atau pembebasan hutang, atau yang diperuntukkan sebagai bukti dari pada sesuatu hal dengan maksud untuk memakai atau menyuruh orang lain memakai surat tersebut seolah-olah isinya benar dan tidak dipalsukan, diancam jika 
pemakaian tersebut dapat menimbulkan kerugian, karena pemalsuan surat, dengan pidana penjara paling lama enam tahun. (2) Diancam dengan pidana yang sama, barang siapa dengan sengaja memakai surat palsu atau yang dipalsukan seolah-olah sejati, jika pemakaian surat itu dapat menimbulkan kerugian.

Autentikasi adalah proses pengecekan identitas seorang pengguna sistem komunikasi pada proses login ke dalam sebuah sistem. Pengguna yang telah lolos pengecekan identitas adalah pengguna resmi pada sistem, orang yang memiliki otoritas atas sistem, atau mungkin aplikasi yang berjalan pada sistem. Penggunaan sistem autentikasi diharapkan dapat membentuk sebuah sistem khusus, yang hanya dapat dipergunakan oleh orang-orang yang memiliki hak guna. Dalam penelitian ini autentikasi difokuskan kepada sertifikat. Dimana sertifikat bisa dicek keasliannya dengan melalui kode verifikasi yang sudah tersedia. Kode verifikasi dibuat berdasarkan dengan kode sertifikat dan juga tanggal pembuatan sertifikat. Hal ini guna mempermudah proses validasi pada sistem yang sudah ada.

\section{PERMASALAHAN}

Dalam proses validasi sertifikat terdapat permasalahan yaitu; untuk proses validasi sertifikat, admin hanya mengecek foto hasil scan dari sertifikat yang sudah di submit. Jika foto yang di submit telah sesuai dengan kriteria maka data sudah dinyatakan valid, sedangkan jika foto yang disubmit untuk sertifikat yang gambarnya tidak muncul atau link gambarnya bermasalah maka data dinyatakan tidak valid. Hal tersebut merupakan ketidak efektifan dari program validasi yang sudah ada, dan tidak ada yang bisa memastikan atas keaslian sertifikat tersebut. Karena masih ada dua potensi yaitu sertifikat tersebut asli atau sertifikat palsu yang merupakan hasil dari aplikasi manipulasi gambar.

Validasi sertifikat dilakukan untuk memenuhi PO (Penilaian Objektif) untuk Sidang. PO terbagi dalam 10 poin dengan jumlah nilai yang berbeda-beda. Dikarenakan dengan adanya suatu nilai (value) dalam poin tersebut maka di khawatirkan mahasiswa yang tidak bisa memenuhi poin tersebut akan melakukan segala cara untuk bisa mendapatkan nilai, salah satunya dengan mensubmit sertifikat palsu hasil manipulasi menggunakan aplikasi.

Solusi agar proses validasi bisa terhindar dari kecurangan yaitu dengan menerapkan sistem untuk mengecek kembali keaslian sertifikat tersebut. Jadi sebenarnya sistem autentikasi sertifikat ini dibuat untuk membantu proses validasi agar lebih efektif dan menghindari kecurangan atas pemalsuan sertifikat. Metode yang diterapkan yaitu mahasiswa telah berhasil mengikuti tridharma, lalu admin memasukkan data dan generate kode verifikasi untuk diletakkan pada sertifikat. Selanjutnya mahasiswa submit sertifikat yang sudah ada kode verifikasinya dan admin mengecek sertifikat dan kode verifikasinya apakah cocok dengan data yang ada di database. Jika data dan kode verifikasi tersebut tidak cocok maka bisa dipastikan sertifikat tersebut palsu, namun jika mahasiswa sudah mengikuti tridharma dan kode tetap tidak ditemukan, bisa saja dalam penginputan data admin mengalami kesalahan. 
Maka alangkah baiknya mahasiswa mengecek dahulu secara mandiri apakah kode verifikasi tersebut sudah terintegrasi ke dalam database atau belum.

\section{METODE PENELITIAN}

1. Dalam penelitian yang dilakukan oleh Edy Djauhari Purwakusumah, Mohamad Rafi, Utami Dyah Safitri, Waras Nurcholis, Muhammad Agung Zaim Adzkiya yang berjudul "Identifikasi dan Autentikasi Jahe Merah Menggunakan Kombinasi Spektroskopi FTIR dan Kemometrik" Spektroskopi FTIR dan kombinasinya dengan analisis komponen utama dan analisis diskriminan telah digunakan untuk identifikasi dan autentikasi jahe merah dari dua spesies yang berkerabat dengannya yaitu jahe emprit dan jahe gajah. Seluruh contoh dibuat spektrum FTIR pada kisaran bilangan gelombang 4000-400 cm-1 dan diberi perlakuan pendahuluan seperti normalisasi dan koreksi garis dasar. Kombinasi spektrum FTIR dengan beberapa metode kemometrik seperti analisis komponen utama dan analisis diskriminan digunakan untuk membedakan ketiga varietas jahe. Analisis diskriminan dapat mengelompokkan ketiga varietas jahe sesuai dengan jenis varietasnya. Metode yang dikembangkan ini dapat digunakan untuk tujuan identifikasi dan autentikasi jahe merah.

2. Dalam penelitian yang dilakukan oleh Deden Yusman Maulid dan Nurilmala yang berjudul "DNA Barcoding untuk Autentikasi Produk Ikan Tenggiri", Kebutuhan produk perikanan terus meningkat seiring dengan pertambahan populasi manusia. Keterbatasan bahan baku menyebabkan meningkatnya biaya produksi dan berpotensi menimbulkan kecurangan perdagangan untuk meningkatkan keuntungan sepihak. Ikan Tenggiri (Scomberomorus $s p$ ) merupakan ikan perenang cepat dan sering digunakan sebagai bahan baku dalam pembuatan produk perikanan. Proses Pengolahan menyebabkan ikan ini sulit dikenali secara morfologi. Pendekatan molekuler melalui amplifikasi DNA menjadi jalan keluar untuk mengetahui keaslian produk yang telah mengalami perubahan bentuk. Sampel yang telah dikumpulkan terdiri dari baso (Sio), empek-empek (PLm), kerupuk pasar tradisional (KrPsa), dan kerupuk pasar modern (KrLM). dan. Produk tersebut berlabel ikan Tenggiri. Primer yang didesain adalah Cytochrome $b$ dengan target $380 \mathrm{bp}$, merupakan salah satu gene penyandi pada DNA mitokondria. Analisis kesejajaran digunakan untuk mengetahui kedekatan kekerabatan species. Berdasarkan hasil penelitian ini, tiga produk yaitu baso, kerupuk dari pasar modern (KrLM), dan empek-empek diketahui menggunakan bahan baku ikan tenggiri, akan tetapi kerupuk yang diperoleh dari pasar tradisional (KrPsa) tidak terlacak menggunakan bahan baku ikan tenggiri.

3. Dalam penelitian yang dilakukan oleh Joseph Bonneau, Cormac Herley, Paul C. van Oorschot, Frank Stajano yang berjudul "The Quest to Replace Passwords: A 
Framework for Comparative Evaluation of Web Authentication Schemes" Kami mengevaluasi dua dekade proposal untuk mengganti kata sandi teks untuk otentikasi pengguna tujuan umum di web dengan menggunakan seperangkat manfaat dua puluh lima kegunaan, deployability dan keamanan yang mungkin disediakan oleh skema ideal. Lingkup proposal yang kami survei juga ekstensif, termasuk perangkat lunak manajemen kata sandi, protokol login federasi, skema kata kunci grafis, skema otentikasi kognitif, satu kali kata sandi, token perangkat keras, skema bantuan telepon dan biometrik. Pendekatan komprehensif kami mengarah pada wawasan penting tentang kesulitan mengganti kata sandi. Tidak hanya skema yang tidak diketahui mendekati pemberian semua manfaat yang diinginkan: bahkan tidak ada set lengkap manfaat yang diberikan oleh kata kunci lawas. Secara khusus, ada beragam pilihan dari skema yang menawarkan sedikit manfaat keamanan di luar kata kunci lawas, yang menawarkan manfaat keamanan yang signifikan sebagai imbalan karena lebih mahal untuk digunakan atau lebih sulit untuk digunakan. Kami menyimpulkan bahwa banyak proposal akademis telah gagal untuk mendapatkan daya tarik karena peneliti jarang mempertimbangkan kendala dunia nyata yang cukup beragam. Di luar analisis kami terhadap skema saat ini, kerangka kerja kami menyediakan metodologi evaluasi dan tolok ukur untuk proposal autentifikasi web masa depan.

4. Penelitian yang dilakukan oleh Ping Guo, Jin Wang, Xue Hua Geng, Chang Seob Kim, Jeong-Uk Kim yang berjudul "A Variable Threshold-Value Authentication Architecture for Wireless Mesh Networks" Menjeleaskan bahwa Wireless Mesh Networks (WMNs) memainkan peran yang sangat penting dalam "mil terakhir" dalam berbagai akses jaringan nirkabel dengan dukungan infrastruktur. Hal ini diperlukan untuk memberikan keamanan yang terjamin sambil meminimalkan perubahan topologi WMN dengan mempertimbangkan otentikasi cepat dari terminal seluler dan permintaan untuk beralih cepat di antara jaringan nirkabel yang berbeda. Dalam makalah ini, kami mengusulkan sebuah paradigma desain baru menuju otentikasi yang ringan dan toleran untuk WMNs berorientasi layanan, yang diberi nama arsitektur Variable Thresholdvalue Authentication (VTA). Di satu sisi, kemampuan toleransi intrusi VTA dipastikan untuk merancang serangkaian mekanisme yang diaktifkan node untuk tetap memiliki nilai ambang batas dan $\mathrm{n}$ kunci privat sistem tidak berubah. Di sisi lain, VTA mengubah nilai ambang $\mathrm{t}$ dan $\mathrm{n}$ ketika node meninggalkan / bergabung dengan grup server otentikasi. Hasil analisis dan simulasi menunjukkan bahwa VTA tidak hanya dapat mengatasi kelemahan skema nilai ambang statis tersebut, namun juga meningkatkan biaya sistem dibandingkan dengan skema yang tidak dilengkapi dengan mekanisme ambang batas untuk WMNs.

5. Dalam penelitian P. Hoffman dan J. Schlyter yang berjudul "The DNS-Based Authentication of Named Entities (DANE) Transport Layer Security (TLS) 
Protocol: TLSA" Komunikasi terenkripsi di Internet sering menggunakan Transport Layer Security (TLS), yang bergantung pada pihak ketiga untuk mengesahkan kunci yang digunakan. Dokumen ini memperbaiki situasi tersebut dengan memungkinkan administrator nama domain menentukan kunci yang digunakan di server TLS domain tersebut. Ini membutuhkan perbaikan yang sesuai pada perangkat lunak klien TLS, namun tidak ada perubahan pada perangkat lunak server TLS.

Dari 5 (lima) Literature Review yang dijelaskan diatas, dapat diambil kesimpulan bahwa sudah banyak penelitian tentang autentikasi yang di tujukan untuk konteks keamanan. Hal tersebut sangat relatable dengan penelitian ini.

\section{HASIL DAN PEMBAHASAN}

Berdasarkan analisis serta penelitian yang dilakukan di dalam sistem yang berjalan saat ini yaitu sistem PESSTA+, maka tahap selanjutnya adalah membahas mengenai sistem usulan. Adapun sistem yang berjalan pada penilaian validasi sertifikat ini akan mengubah proses validasi agar menjadi lebih optimal. Dimana mahasiswa tetap akan submit validasi sertifikatnya ke sistem PESSTA+ dan selanjutnya petugas PESSTA+ bisa cek validitas dan keaslian sertifikat tersebut secara mendetail. Selanjutnya jika hasil submit itu benar dan valid maka nilai PO Sertifikat mahasiswa tersebut sudah langsung ada di sistem PESSTA+.

Setelah dilakukannya observasi dari berbagai permasalahan yang sedang dihadapi saat ini, maka dicarikan alternatif pemecahan masalah yang mendukung dan bisa menjadi referensi bagi Perguruan Tinggi Raharja. Terdapat 3 alternatif pemecahan masalah, diantaranya yaitu;

1. Dengan dibuatnya sistem autentikasi sertifikat diharapkan supaya kedepannya tidak ada manipulasi data dari mahasiswa untuk mendapatkan penilaian objektif.

2. Dengan hadirnya sistem autentikasi sertifikat ini dapat menghasilkan data-data dari tridharma ataupun seminar secara terdokumentasi untuk meminimalisir kehilangan data.

3. Dan dengan dibuatnya autentikasi sertifikat ini dapat dikembangkan sistem baru seperti sertifikat online sehingga mahasiswa mempunyai file sertifikat tersendiri dan bisa mencetak sertifikat secara mandiri.

Berikut ini merupakan tampilan dari program autentikasi sertifikat dan juga testing yang sudah dilakukan. Misalnya ketika user memasukkan kode yang benar bagaimana tampilan yang akan muncul, dan juga ketika user memasukkan kode yang salah atau tidak tepat bagaimana tampilan yang akan muncul. 
1. Pada halaman utama terdapat kolom search untuk memasukkan kode verifikasi.

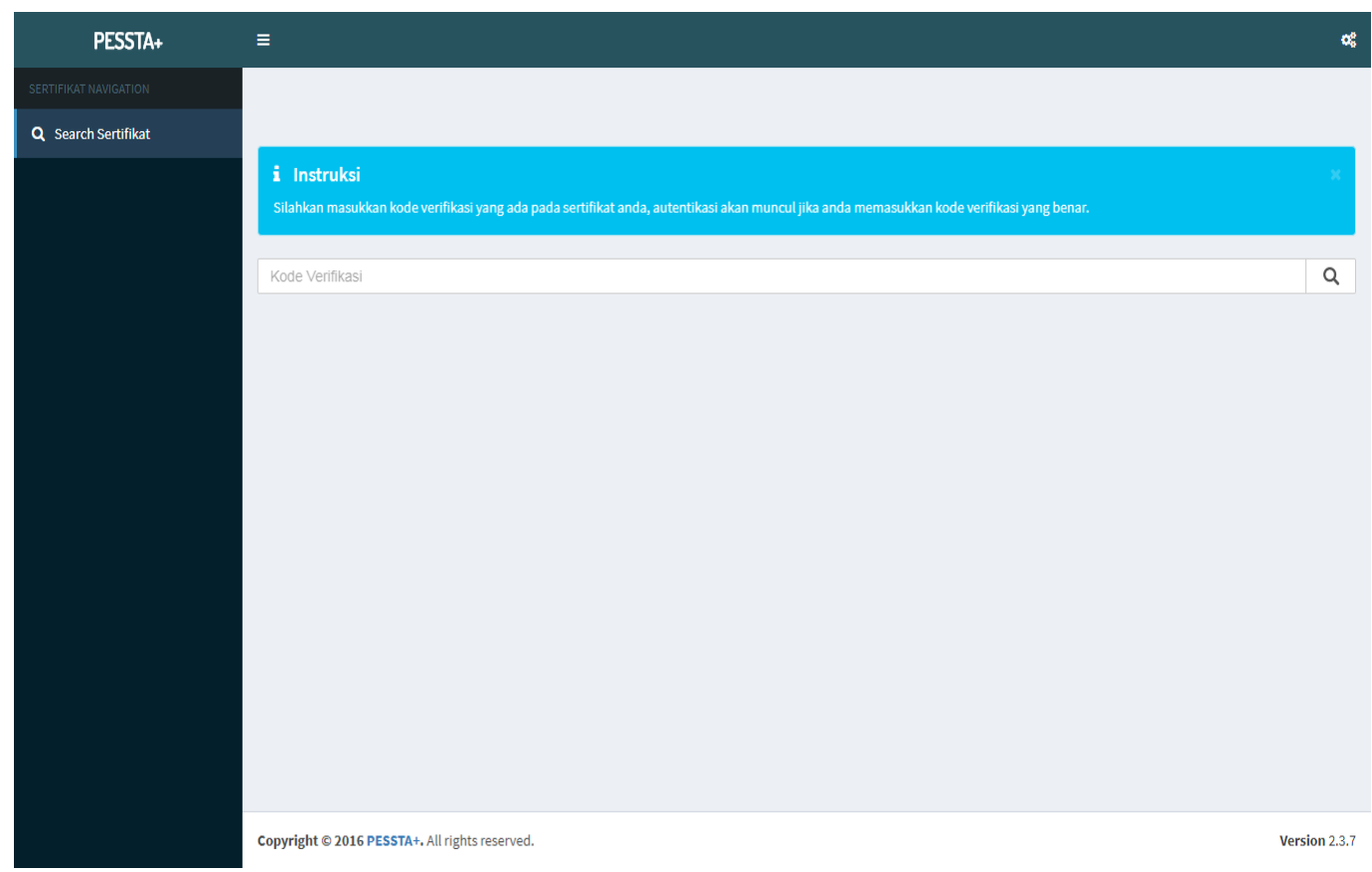

Gambar 1: Tampilan Utama Dari Sistem Autentikasi Sertifikat

2. Memasukkan kode verifikasi yang benar, mengacu pada kode yang ada di sertifikat.

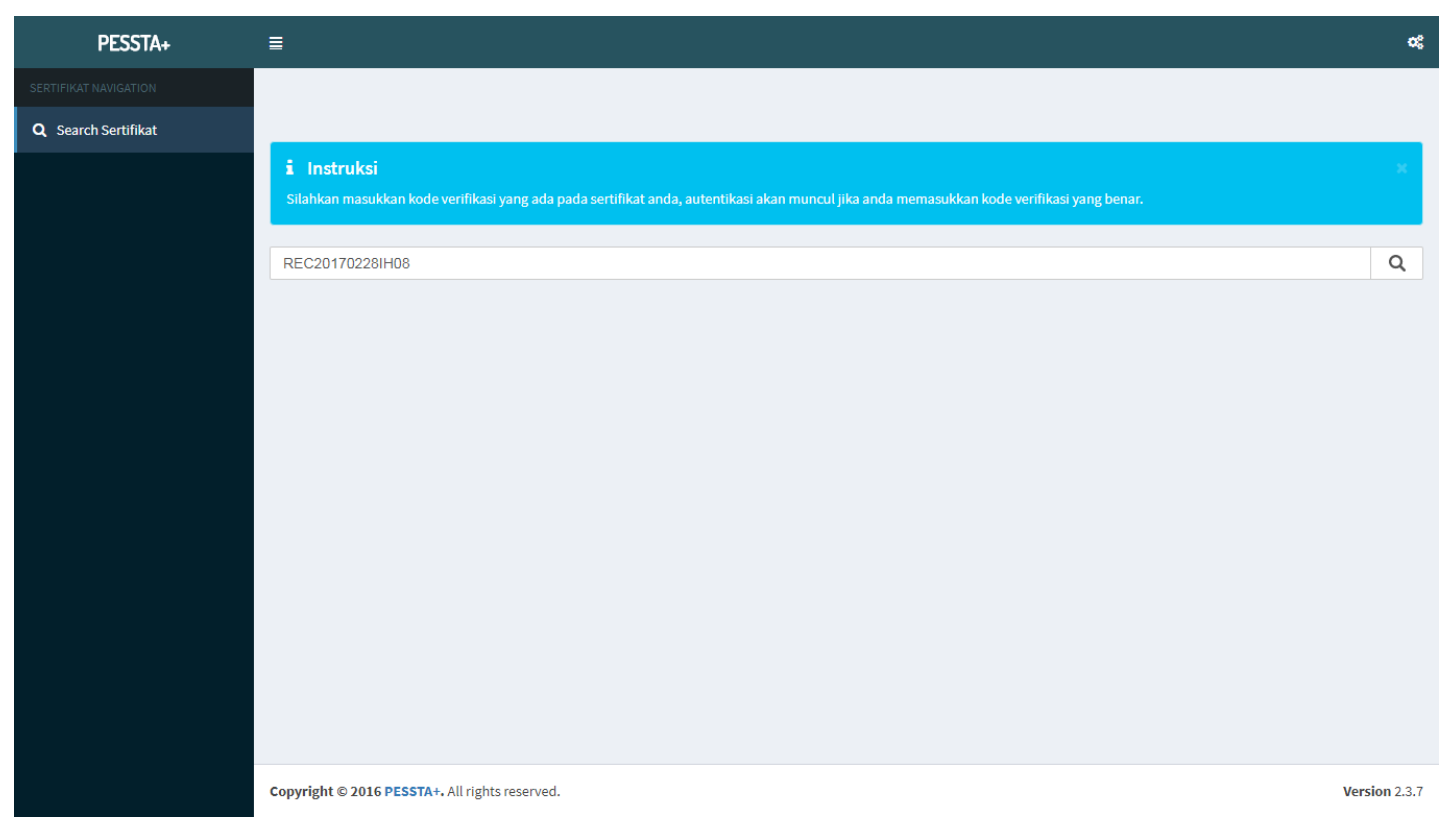

Gambar 2 : Memasukkan kode verifikasi 
3. Keterangan sertifikasi yang muncul, ada tanggal sertifikat, nama mahasiswa, dan nama sertifikasi. Jika sertifikasi tersebut dari tridharma maka akan ada nama tridharma yang dijalani, namun jika sertifikasi tersebut dari seminar maka akan ada nama seminar yang diikuti.

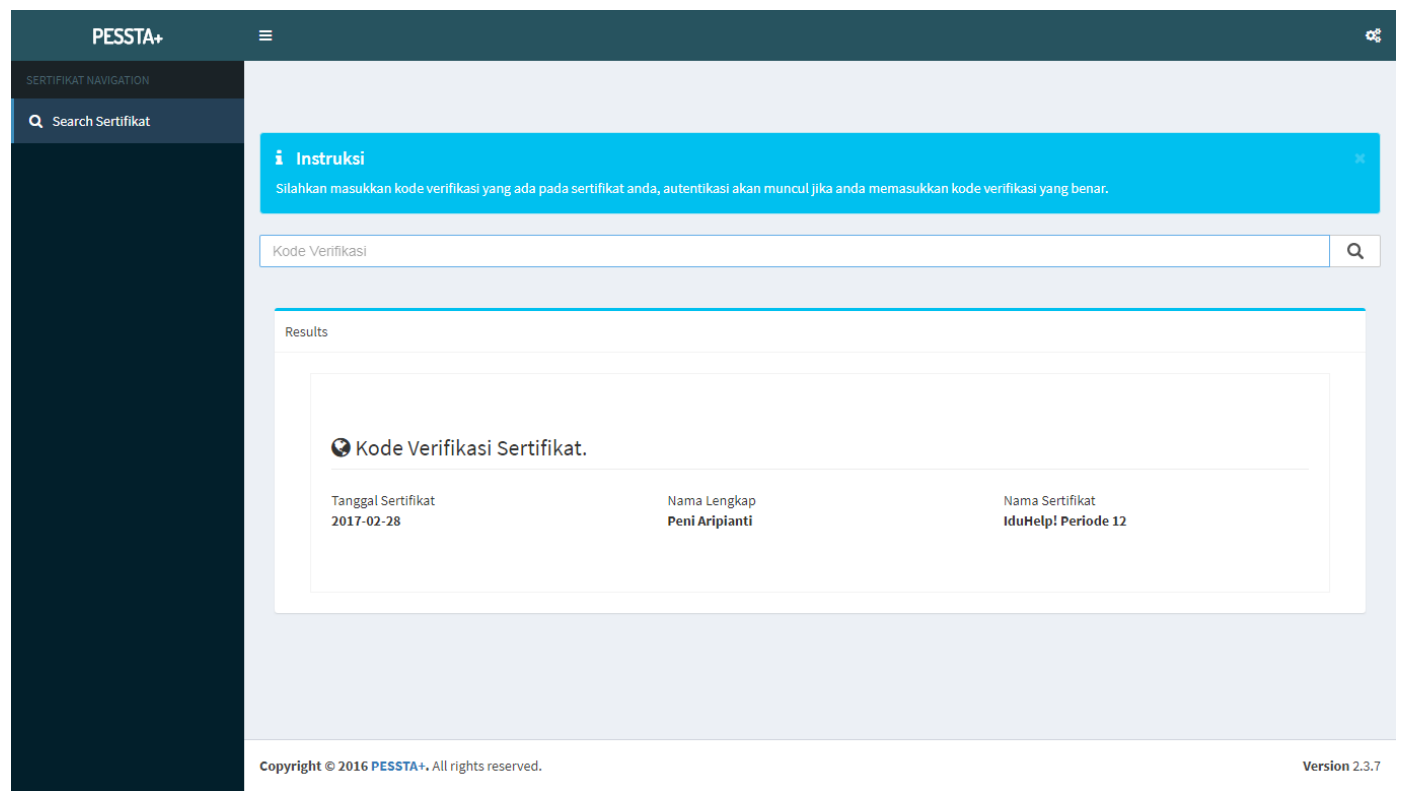

Gambar 3: Keterangan Sertifikat yang Asli dan Benar

4. Mencoba memasukkan kode random yang tidak ada di sertifikat.

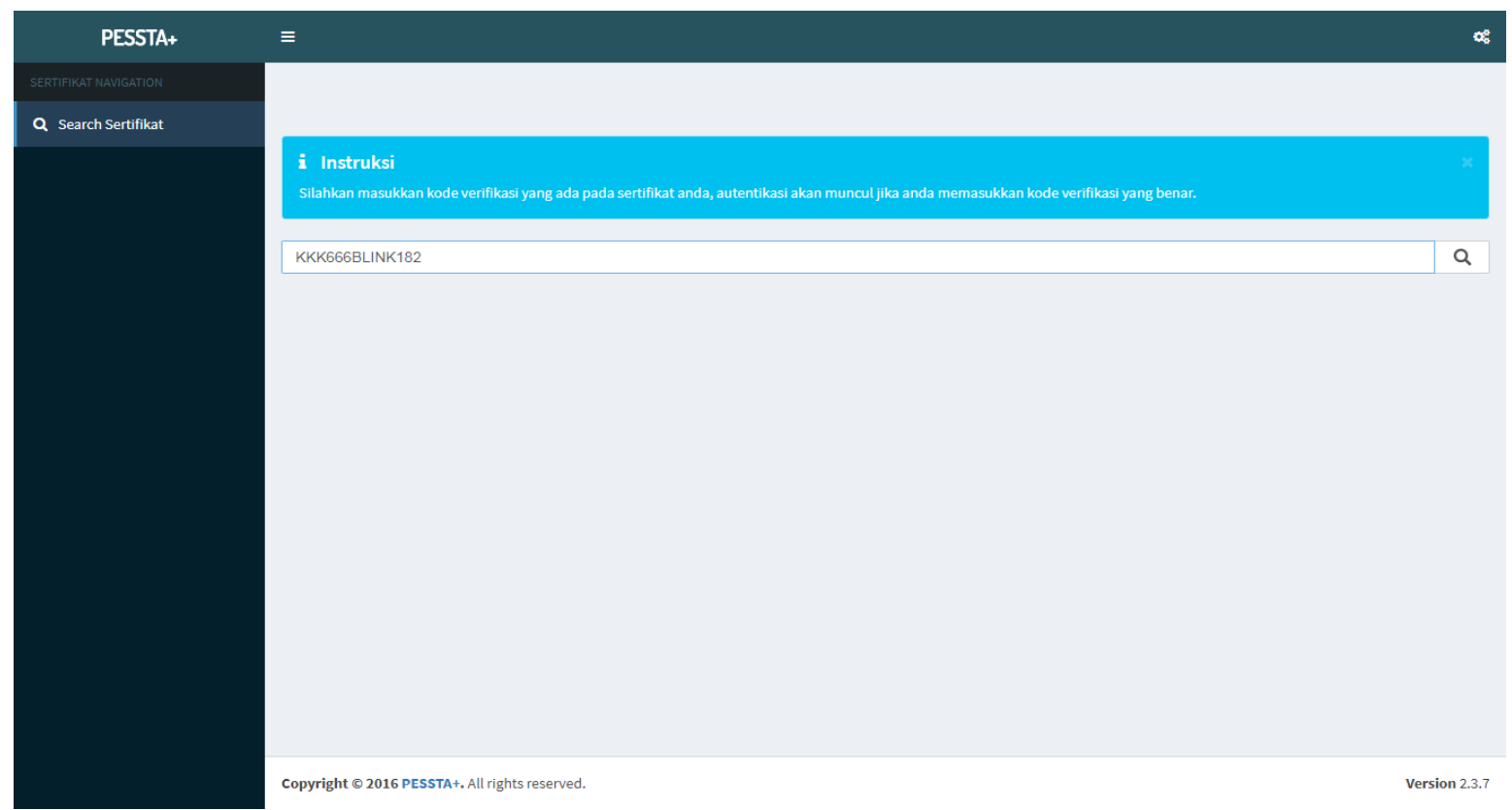

Gambar 4: Tampilan kode random yang tidak ada di database. 
5. Tampilan yang muncul jika kode verifikasi sertifikat salah atau tidak tepat.

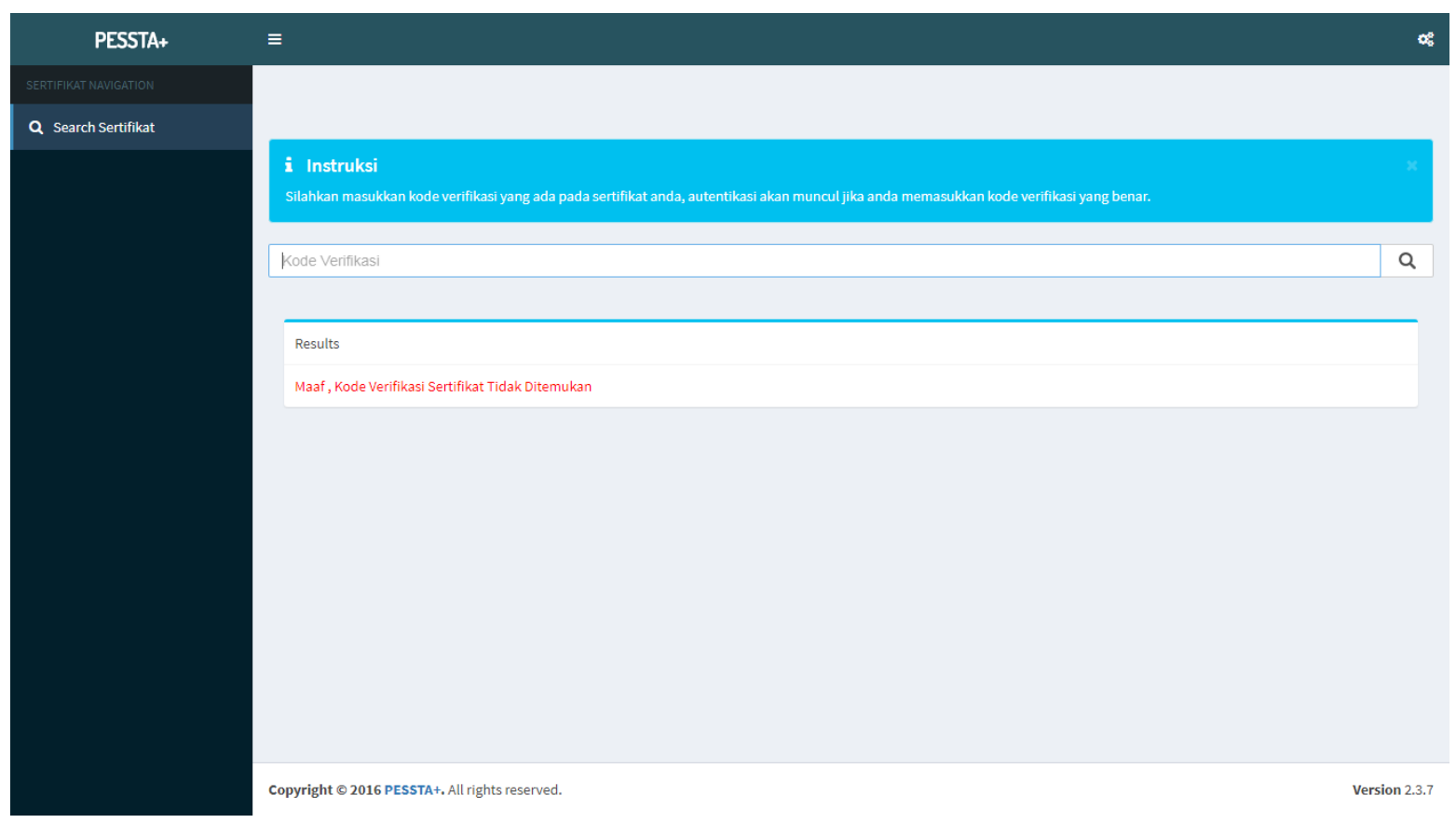

Gambar 5 : Tampilan Kode Salah yang tidak terdapat pada database

\section{KESIMPULAN}

Dengan diterapkannya sistem autentikasi sertifikat ini dapat menjadikan sistem validasi sertifikat yang sudah berjalan sebelumnya menjadi lebih optimal serta menghindari mahasiswa dan mahasiswi untuk melakukan pemalsuan sertifikat untuk mendapatkan poin Penilaian Objektif sidang juga dapat meningkatkan kinerja petugas dan admin validasi. Dengan adanya sistem autentikasi sertifikat menjadikan Perguruan Tinggi Raharja semakin kompeten sebagai Perguruan Tinggi di bidang Komputer.

\section{SARAN}

Untuk memajukan sistem tersebut diperoleh beberapa saran yang dapat dijadikan sebagai referensi, diantaranya yaitu:

1. Diharapkan dapat dikembangkan supaya lebih baik dan ruang lingkupnya lebih luas.

2. Supaya proses validasi menjadi lebih efektif dan maksimal.

3. Untuk pengembang selanjutnya saya sarankan untuk lebih giat dan teliti. 


\section{DAFTAR PUSTAKA}

[1] Purwakusumah, Edy Djauhari, dkk. "Identifikasi dan autentikasi jahe merah menggunakan kombinasi spektroskopi FTIR dan kemometrik." Agritech 34.1 (2014): 82-87.

[2] Maulid, Deden Yusman. "DNA Barcoding untuk Autentikasi Produk Ikan Tenggiri (Scomberomorus sp)." Jurnal Akuatika 6.2 (2015).

[3] Bonneau, Joseph, et al. "The quest to replace passwords: A framework for comparative evaluation of web authentication schemes." Security and Privacy (SP), 2012 IEEE Symposium on. IEEE, 2012.

[4] Guo, Ping, et al. "A variable threshold-value authentication architecture for wireless mesh networks." 網際網路技術學刊 15.6 (2014): 929-935.

[5] Schlyter, Jakob, and Paul Hoffman. "The DNS-based authentication of named entities (DANE) transport layer security (TLS) protocol: TLSA." (2012). 